\title{
MONITORING THE ECOLOGICAL ENVIRONMENT OF OPEN-PIT COALFIELDS IN COLD ZONES OF NORTHEAST CHINA USING LANDSAT TIME SERIES IMAGES OF 2000-2015
}

\author{
Wenbin Sun, Hongdan Zhang, Yungang Cao, Xiaolei Zhang, Xuefeng Ji, Fashuai Li
}

Original scientific paper

Evaluating the deterioration of ecological environment and vegetation of coalfields caused by China's large-scale coal mining activities is important because of the fragile ecological environment and low temperature in cold and arid areas. This study takes the open coal pits of Haizhou, Gulianhe, and Huolinhe as examples and proposes a method for evaluating their ecological environment using Landsat time series images based on the Normalized Difference Vegetation Index (NDVI) variations of open-pit coalfields in cold and arid zones. The average NDVI value of the mining area each month was calculated using Landsat image data from 2000 to 2015. The vegetation cover area in the coalfields was extracted according to the NDVI threshold, and the scatter plots of the annual maximum NDVI and vegetation cover area were drawn. We fitted the variation trend line of maximum NDVI value and vegetation cover area to reduce the effect of meteorological factors on NDVI values. Results show that after the closure of open pit and reclamation of dump area, the NDVI of open-pit coalfields and vegetation cover area have been increasing rapidly over the last decade, and the ecological environment of these coalfields has obviously improved. The coal mining activities have led to the rapid decline of annual maximum NDVI and vegetation cover area of the coalfields in permafrost zones, and the ecological environment of coalfields continues to deteriorate. Although the quarterly average NDVI remains unchanged in non-permafrost mining coalfields under coal exploitation, the vegetation cover area in the coalfields decreases linearly, indicating that the ecological environment of the coalfields tends to deteriorate. From an ecological environment protection perspective, the results of this study provide a basis for decision making in constructing large-scale open pits in cold and arid zones.

Keywords: coalfield; ecological environment; Landsat data set; Normalized Difference Vegetation Index (NDVI); time series

\section{Praćenje ekološkog okruženja rudnika s otvorenim jamskim oknom u hladnim područjima sjeveroistočne Kine primjenom Landsat serije slika snimljenih u razdoblju 2000-2015}

Izvorni znanstveni članak

Procjena pogoršanja ekološkog okruženja i vegetacije rudnika u Kini zbog prekomjernog vađenja ugljena važna je zbog osjetljivog ekološkog okruženja i niske temperature $u$ hladnim $i$ sušnim područjima. U ovom se istraživanju kao primjeri uzimaju rudnici Haizhou, Gulianhe i Huolinhe s otvorenim jamskim oknom te se predlaže metoda za procjenu njihovog ekološkog okruženja primjenom Landsat vremenske serije slika na temelju varijacija Normalized Difference Vegetation Index-a (NDVI) rudnika s otvorenim jamskim oknom u hladnim i sušnim područjima. Prosječna NDVI vrijednost rudarskog područja izračunavala se svakog mjeseca primjenom podataka Landsat serije slika od 2000 do 2015 . Područje nalazišta ugljena pod vegetacijom određeno je u skladu s graničnim vrijednostima NDVI pa su tako izrađeni grafikoni godišnjeg maksimalnog NDVI i područja pod vegetacijom. Prilagodili smo liniju trenda varijacije maksimalne vrijednosti NDVI i područja pod vegetacijom kako bi se smanjio učinak meteoroloških čimbenika na NDVI vrijednosti. Rezultati pokazuju da se poslije zatvaranja jame i čišćenja područja odlaganja, naglo, tijekom zadnjeg desetljeća, povećao NDVI rudnika s otvorenim jamskim otvorom i područja pod vegetacijom, a ekološko okruženje tih rudnika se očito poboljšalo. Rudarske aktivnosti su dovele do naglog opadanja godišnjeg maksimalnog NDVI i područja pod vegetacijom s trajno smrznutim slojem tla, a ekološko okruženje rudnika se nastavlja pogoršavati. Premda četverogodišnji prosječni NDVI ostaje nepromijenjen u dijelovima nalazišta ugljena koji se eksploatiraju, a nemaju trajno smrznuti sloj tla, područje ugljenokopa pod vegetacijom se linearno smanjuje, ukazujući na činjenicu da se ekološko okruženje ugljenokopa pogoršava. Sa stajališta zaštite ekološkog okruženja, rezultati ovog istraživanja čine osnovu za donošenje odluke o otvaranju velikih rudnika s otvorenim jamskim oknom u hladnim i sušnim područjima.

Ključne riječi: ekološko okruženje; Landsat niz podataka; Normalized Difference Vegetation Index (NDVI)(indeks normalizirane razlike vegetacije); ugljenokop; vremenska serija

\section{Introduction}

Environment monitoring and evaluation of coalfields are particularly important because mining activities cause a series of ecological and environmental problems, such as forest degradation and groundwater lowering $[1 \div 6]$. Satellite remote sensing is an effective tool for evaluating the ecological environment of coalfields. The large areas of the ecological environment can be monitored easily using satellite-based sensors. Many scholars have used remote sensing images to monitor and study the ecological environment of open pits $[1,4 \div 8]$. In the past 20 years, ecological evaluation indexes, such as Simple Ratio Index (SRI) and Normalized Difference Vegetation Index (NDVI), have also been extensively used in assessing the ecological environment of open pits. NDVI is one of the most widely used indices because vegetation is an indicator of the ecological environment. In this study, NDVI is selected as the index for evaluating the ecological environment of coalfields $[8 \div 10]$.
Generally, ecological evaluation methods of coalfields involve selecting remote sensing images every few years, comparing and analyzing the NDVI variations of the coalfields using the selected images, and then evaluating the ecological environment of the coalfields according to NDVI variations. Although these methods are suitable for most coalfields, the meteorological factors in cold and arid zones greatly influence the NDVI of different years; therefore, the above methods are inapplicable to the ecological environment monitoring of open pits in cold and arid zones. The annual average temperature and precipitation are relatively lower in cold and arid zones than in warm and humid areas, and the temperature and the precipitation of different years vary greatly. The influence of meteorological factors on NDVI variations should not be disregarded. Figuring out how to effectively monitor the ecological environment of coalfields in cold and arid zones is urgent. 


\section{State of the art}

Most of the studies have confirmed the importance of NDVI in coalfield monitoring and vegetation health

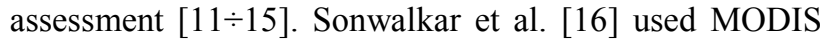
(MODerate-resolution Image Spectroradiometer) NDVI products to analyze the variations of acid mine drainage. Erener [1] analyzed the vegetation cover and health status of the reclaimed area of Seyitömer mine using NDVI, SRI, and reduced simple ratio. Townsend et al. [17] examined the land use changes of central Appalachian Mountain region in the eastern United States using decision trees and Landsat time series data. Zhang et al. [18] based their research on HyMap and Hyperion image data used in Vegetation Inferiority Index and adopted Water Absorption Disrelated Index and NDVI; they also investigated and evaluated the effect of mining activities on the environment. Vasileiou et al. [9] analyzed the ecological environment changes of coalfields using NDVI after the mine is closed. Zawadzki et al. [19] analyzed the effect of mining activities on the ecological environment of Lignite Mine depression cone using Landsat $\mathrm{TM} / \mathrm{ETM}+$ data and explored the relationship between surface temperature and NDVI. Tian et al. [20] evaluated the trend of NDVI variations of the coalfields in Loess Plateau using the blended data of Landsat and MODIS. Lei et al. $[3,21]$ investigated the NDVI variations in the mining and non-mining area using MODIS NDVI products and Landsat TM images of 2000, 2002, and 2005. The results showed that the NDVI of coalfields (e.g., Bulianta) exhibited different degrees of decline.

Although NDVI is widely used in the environmental monitoring of coalfields, this index is affected by both climate change and mining activities. If only the NDVI values of two images are used to analyze vegetation health and ecological environment, then eliminating the influence of meteorological factors is infeasible. If the time series image is used to analyze the changes of vegetation health and cover area in the coalfields, then the effect of meteorological factors on the analysis results of NDVI variations is minimized. Many scholars also used time series images to conduct studies on the environmental monitoring and assessment of coalfields. Liu et al. [22] analyzed the changes of vegetation cover area using image data from 1990 to 2015. Lei et al. [3] used MODIS NDVI time series images to analyze the environmental changes of Shendong coalfields caused by underground mining. Although the methods of evaluating ecological environment has been proposed based on NDVI variations, the influence of meteorological factors on NDVI variations is neglected especially in cold zones. Therefore, we study and analyze the influence of mining activities on the ecological environment using time series images and trend line of NDVI variations under different climatic types in cold areas of Northeast China.

The sections of the paper are arranged as follows. In the third section, the research scope, data, and method are introduced. In the fourth section, the vegetation cover area of coalfields and NDVI variations are analyzed. The correlation between NDVI variations and meteorological factors is analyzed and the determination coefficients of NDVI, temperature, and precipitation are determined. In this section, the results indicating that the NDVI variations of coalfields are mainly affected by mining activity are also discussed. In the fifth section, the conclusion is presented.

\section{Methodology \\ 3.1 Study area}

Northeast China is one of the areas where open pits with longest mining history and largest mining scale in China are located. Haizhou open pit was the first largescale, mechanization-based open-pit coalfield after new China was founded; it was closed in 2005. After the production is suspended, Haizhou open pit was rebuilt and converted into a national mine park. Huolinhe is one of China's five largest open-pit coalfields, and Gulianhe coalfield is the only open-pit coalfield located in the permafrost zones of China. In this study, we regarded Gulianhe, Huolinhe, and Haizhou open pits in Northeast China as the study zones. Fig. 1 illustrates the spatial location and geomorphological features of each coalfield.

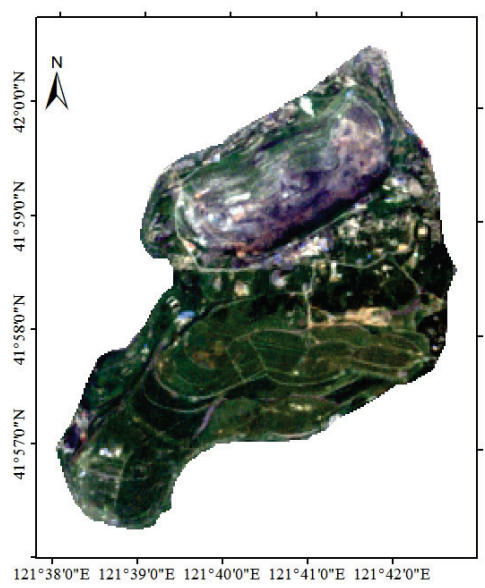

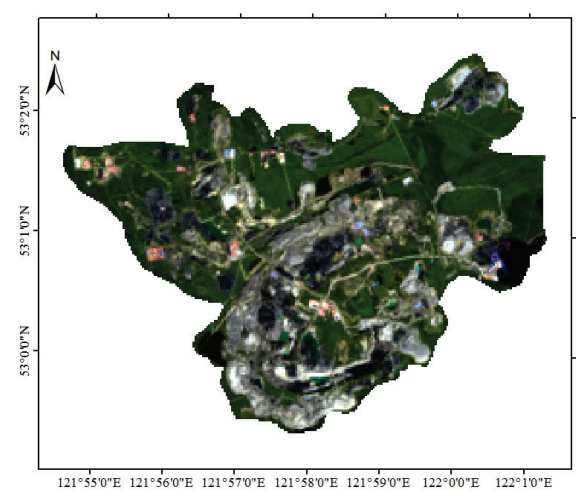

b)

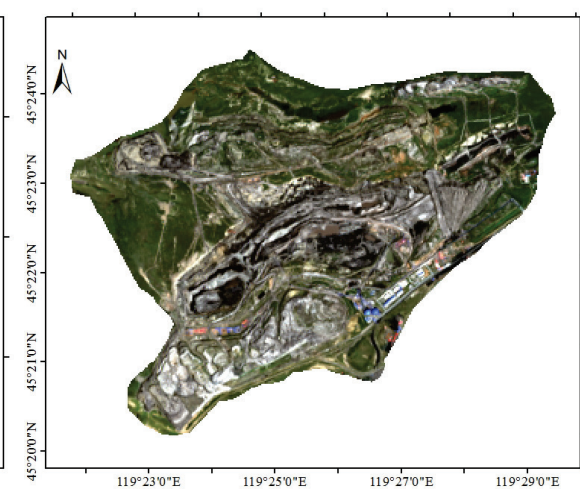

c)

Figure 1 a) Ecological environment, Normalized Difference Vegetation Index (NDVI), Coalfield, Time series, Landsat data set; b) Gulianhe open pit coalfield; c) Huolinhe open pit coalfield

Haizhou open pit is of northern temperate semihumid and semi-arid climate. The annual average temperature of the coalfield is between $6,4^{\circ} \mathrm{C}$ and $9,3{ }^{\circ} \mathrm{C}$, and the average annual precipitation is $534,6 \mathrm{~mm}$. The 
vegetation in the coalfields belongs to the flora limbic system of North China, where xeric plants and shrubs communities are distributed, and their vegetation cover areas are between $10 \div 50 \%$ and $30 \div 50 \%$, respectively. Gulianhe is a unique coalfield in the permafrost stratum on the northern most end of China. The Gulianhe open-pit coalfield typically experiences cold temperate continental monsoon climate, with an annual average temperature of $-2{ }^{\circ} \mathrm{C}$ in $1999 \div 2015$ and average annual precipitation of $458.1 \mathrm{~mm}$. The main plant in the coalfields is larch Larix. For the Huolinhe open pit, the annual average temperature of $2000 \div 2015$ is $6,94{ }^{\circ} \mathrm{C}$, and the average annual precipitation of coalfields from 2001 to 2015 is $374,8 \mathrm{~mm}$. The coalfield is mainly covered by non-zonal meadow and salt meadow vegetation.

\subsection{Data source}

In this study, we researched and analyzed the spatial variation characteristics of NDVI of coalfields using the data from three resource satellites of Landsat 5, 7, and 8 . The NDVI of coalfields was extracted through bands of B3 and B4 of Landsat 5 and 7, B4 and B5 of Landsat 8. For the Haizhou, Gulianhe, and Huolinhe coalfields, we selected 177, 155, and 163 Landsat images from 1996 to 2015,1999 to 2015 , and 2000 to 2015 , respectively.

Meteorological factors are important factors affecting the NDVI variations; temperature and precipitation factors are closely related to NDVI. We used the monthly mean temperature and cumulative precipitation data of Haizhou, Gulianhe, and Huolinhe coalfields to analyze the correlation between NDVI variations and meteorological factors. Meteorological data were obtained from the meteorological sites located in each coalfield.

\subsection{Calculation of NDVI of coalfields}

NDVI is the vegetation index obtained through combined operation between red and near-infrared spectral channels based on the manifestation characteristics of plants toward different wave bands. Plant leaf tissue can strongly absorb red light and reflect near-infrared light. The higher the vegetation coverage, the smaller the red reflectance; the higher the reflectance of near-infrared light, the higher the NDVI. NDVI can characterize the growth state of vegetation. The mathematical expression of NVDI is

$$
N D V I=\frac{N I R-r e d}{N I R+r e d}
$$

where NIR represents a near-infrared spectral characteristic and red represents the red band spectral characteristics, with the ratio within the range of $[-1,1]$.

To obtain accurate NDVI values, the original image requires preprocessing, which mainly includes image registration, cutting mosaic, atmospheric correction, and image enhancement. Fig. 2 illustrates the specific process.

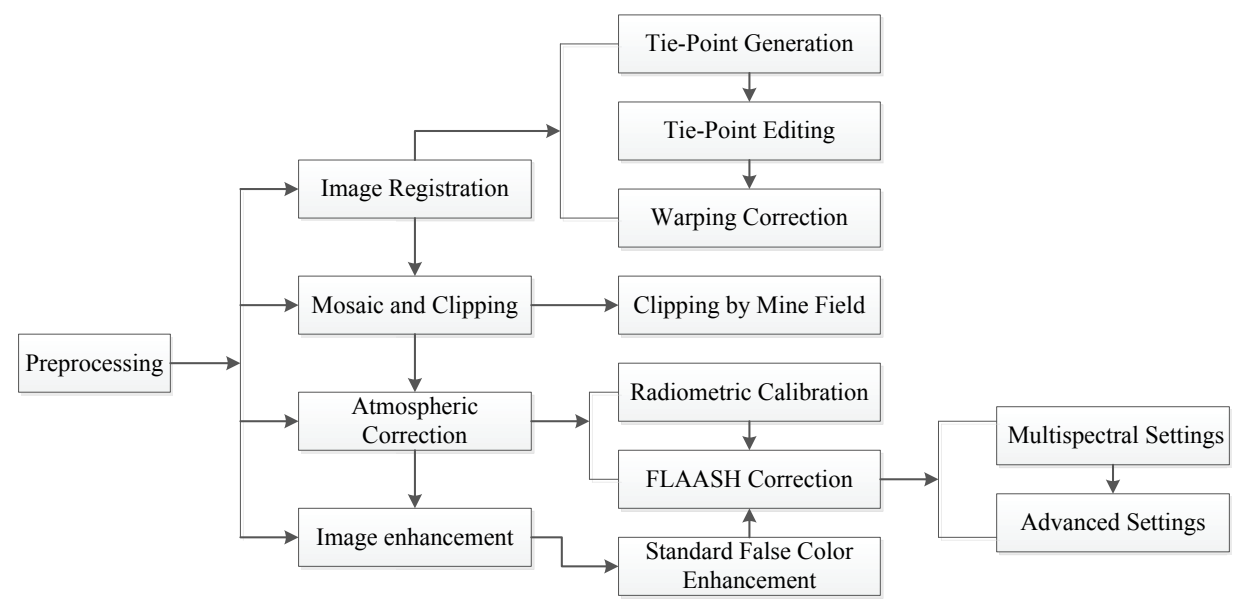

Figure 2 Image preprocessing

The changes of vegetation cover area in the coalfields and NDVI mean value can reflect the variation tendency of the ecological environment of the coalfields. The NDVI of each pixel is calculated using red and nearinfrared bands of Landsat images, and the NDVI outliers are filtered out. To calculate the NDVI variations of coalfields, supervised classification and NDVI threshold methods should be used to filter the non-vegetation cover area (e.g., water bodies, roads, buildings, and pits) in the coalfields. Then, we calculated the NDVI value of vegetation cover area according to Formula 1. We also generated the statistics of average NDVI of the vegetation cover area in the coalfields and depicted the NDVI distribution in the coalfields. Based on the NDVI annual maximum value, the quarterly average value and vegetation cover area of more than 10 years in the coalfields, we drew the corresponding scatter plots. By adapting the NDVI and vegetation cover area fitting line, we obtained accurate ecological changes in the coalfields.

\section{Result analysis and discussion 4.1 Variation tendency of NDVI in Haizhou coalfield}

Tab. 1 lists the monthly average NDVI of vegetation coverage area in Haizhou coalfield from 1996 to 2005. After the closure of Haizhou open-pit coalfield in 2005, the annual average and maximum value of NDVI of the coalfield have obviously improved. The annual averages of NDVI values and the maximum NDVI value average of Haizhou coalfield from $1996 \div 2005$ are 0,240 and 
0,458 , respectively; the annual averages of NDVI values and the maximum NDVI value average of Haizhou coalfield from $2006 \div 2015$ are 0,313 and 0,580 , respectively. The results improved by $30,4 \%$ and $26,6 \%$, respectively. To reduce the influence of different meteorological factors among different years on NDVI, we drew the scatter plot of the maximum NDVI from $1996 \div 2015$, adjusting the fitting line of the annual maximum value of NDVI, with a slope of 0,0116 (Fig. 3).
Fig. 3 shows that the maximum value of NDVI in Haizhou coalfield rapidly increased from 1996 to 2015, the trend of NDVI growth became more remarkable especially after the closure in 2005. The diagram of variation tendency of the vegetation coverage area in the coalfield is shown in Fig. 4, and the slope of the fitted line is 0,282 . In Fig. 4, as the NDVI of the coalfield increased, the vegetation coverage area showed a rapid growth trend.

Table 1 Monthly mean NDVI values of vegetation cover area in Haizhou coalfield

\begin{tabular}{|c|c|c|c|c|c|c|c|c|c|c|c|c|}
\hline Year & Jan & Feb & Mar & Apr & May & Jun & Jul & Aug & Sep & Oct & Nov & Dec \\
\hline 1996 & 1 & 0,217 & 0,136 & 1 & 0,169 & 0,195 & 0,325 & 0,507 & 0,329 & 1 & 1 & 0,218 \\
\hline 1997 & 0,141 & 0,174 & 0,161 & 0,147 & 0,132 & 0,300 & 0,380 & 1 & I & 0,285 & 0,202 & 0,192 \\
\hline 1998 & 0,219 & 0,130 & 0,184 & 1 & 0,155 & 1 & 0,325 & 0,345 & 0,399 & 0,214 & 1 & 0,212 \\
\hline 1999 & 0,248 & 0,142 & I & 0,169 & 0,204 & 0,247 & 0,359 & 0,534 & 0,380 & 0,296 & 0,195 & 0,138 \\
\hline 2000 & 0,068 & 0,106 & 0,188 & 0,126 & 0,214 & 0,261 & 1 & 0,429 & 0,184 & 0,374 & 0,174 & 0,172 \\
\hline 2001 & 1 & 0,108 & 0,167 & 0,153 & 0,122 & 0,292 & 1 & 0,481 & 0,385 & 0,254 & 0,201 & 0,126 \\
\hline 2002 & 0,225 & 0,199 & I & 0,186 & 0,245 & 0,405 & 0,355 & 0,454 & 0,428 & 0,228 & 0,188 & 0,081 \\
\hline 2003 & I & 0,199 & 0,135 & 0,151 & 1 & 0,381 & 1 & 1 & 1 & 0,276 & 1 & I \\
\hline 2004 & 1 & 0,187 & 0,163 & 1 & 0,187 & 0,119 & 1 & 0,499 & 0,226 & 0,279 & 0,145 & 1 \\
\hline 2005 & 1 & 0,178 & 0,164 & 0,156 & 0,184 & 1 & 0,521 & 0,351 & 0,392 & 0,354 & 0,156 & 0,108 \\
\hline 2006 & I & 0,056 & I & 0,031 & 1 & 0,349 & 0,484 & 0,295 & 0,449 & 0,348 & 0,229 & 0,162 \\
\hline 2007 & 0,141 & 0,097 & 0,055 & 0,099 & 1 & 0,147 & 0,444 & 0,544 & 0,507 & 0,419 & 1 & 1 \\
\hline 2008 & 1 & 0,175 & 0,141 & 0,134 & 0,246 & 0,292 & 0,180 & 0,534 & 0,374 & 0,147 & 0,194 & 1 \\
\hline 2009 & 1 & 0,084 & 0,214 & 0,182 & 0,208 & & 0,512 & 0,582 & 0,452 & 0,379 & 0,216 & \\
\hline 2010 & 1 & 1 & 1 & 1 & 1 & 0,445 & 0,466 & 0,640 & 0,518 & 0,394 & 1 & / \\
\hline 2011 & 0,210 & 0,209 & 0,230 & 1 & 1 & 0,365 & 1 & 1 & 1 & 0,381 & 0,322 & 0,205 \\
\hline 2012 & / & 1 & 0,094 & 1 & 0,333 & / & 1 & 0,604 & 0,559 & 0,362 & 0,200 & 1 \\
\hline 2013 & 1 & 1 & 0,187 & 0,150 & 0,334 & 0,453 & 0,737 & 0,653 & 0,424 & 0,226 & 0,333 & 0,178 \\
\hline 2014 & 1 & 0,172 & 0,198 & 0,101 & 0,095 & I & 0,693 & 0,625 & 0,432 & 0,356 & 0,217 & I \\
\hline 2015 & 0,308 & 0,032 & 0,025 & 0,036 & 0,065 & 0,603 & 1 & 0,562 & I & 0,096 & 1 & 1 \\
\hline
\end{tabular}

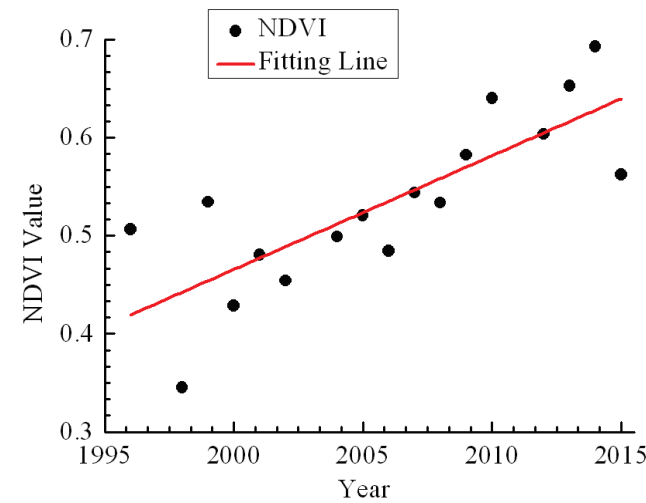

Figure 3 Trend of annual maximum NDVI in Haizhou coalfield

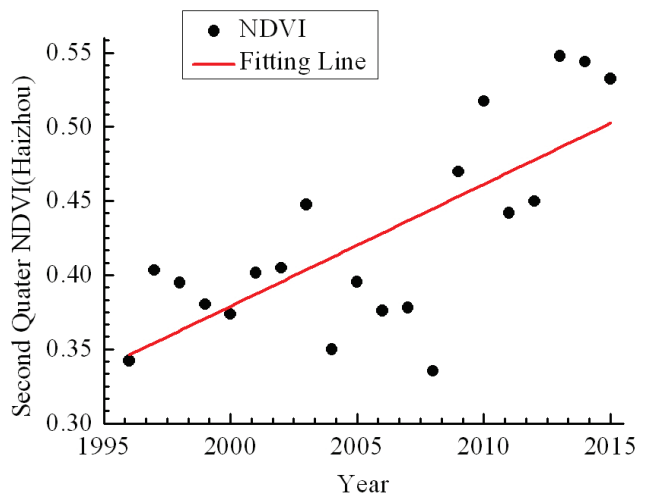

(a) Second quarter

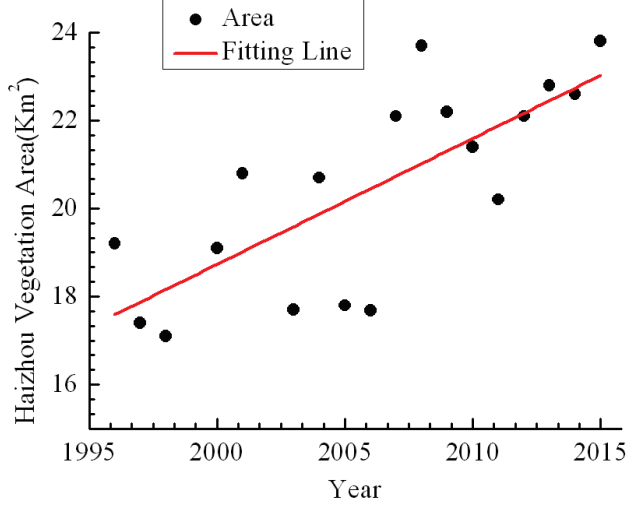

Figure 4 Trend of vegetation cover area in Haizhou coalfiled

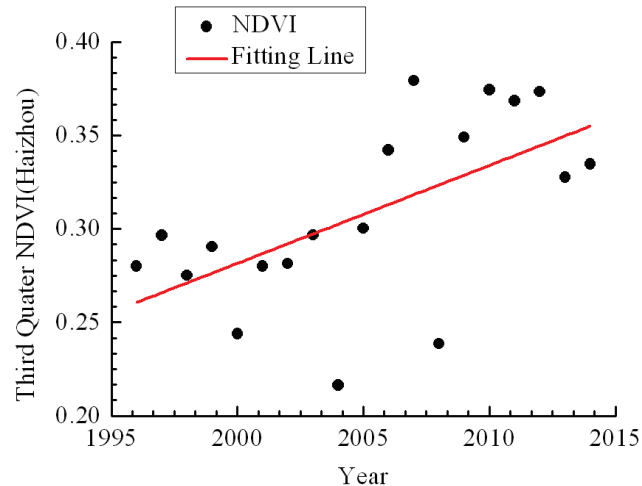

(b) Third quarter

Figure 5 Average seasonal NDVI trends in Haizhou coalfield

To analyze the NDVI variations of the coalfield in different quarters, we first calculated the average of
NDVI for each quarter and plotted the variation of the quarterly average NDVI of the Haizhou coalfield from 
1996 to 2015 (Fig. 5). Between 1996 and 2015, the average NDVI of the Haizhou open pit in the first quarter was between 0,12 and 0,22 , and the slope of the fitted line was 0,00124 ; the average NDVI in the second quarter was between 0,33 and 0,55 , and the slope of the fitted line was 0,00824 ; the average NDVI in the third quarter was between 0,23 and 0,38, and the slope of the fitted line was 0,00524; the average NDVI in the fourth quarter was between 0,11 and 0,23 , and the slope of the fitted line was $-0,00031$.The averages of the second and the third quarters show an increasing tendency, indicating that vegetation growth of the Haizhou coalfield was improving in the second and third quarters annually from $1996 \div 2015$; the improving trend of NDVI in the second quarter is obviously higher than that in the third quarter. The temperatures in the second and third quarters are relatively high, and the tendency of vegetation growth has obviously improved. To display the spatial distribution and change of vegetation health, we plotted the spatial distribution of NDVI using the August data in 1997, 2006, and 2015 (Fig. 6). The pit of Haizhou coalfield is located on the north side of the mine, and the dump areas in the coalfield are mainly distributed on the east and south of the pit. These areas are the non-vegetation cover areas (Fig. 6a). The vegetation in the central part of the coalfield is dominated by trees, and the southern part is dominated by shrubs, forming the spatial distribution characteristics of high NDVI value in the central part of the coalfield and low NDVI value in other parts of the area. With the closure of Haizhou open pit and the implementation of ecological environment restoration, the non-vegetation cover area in the coalfield gradually decreases. From the spatial distribution diagram (Fig. 6c) of NDVI in August 2015, the main non-vegetation cover areas are mainly distributed in the pit and surrounding areas; other areas of the coalfield are vegetation cover areas. Compared to the distribution diagram of NDVI in 1997 and 2006, the NDVI values of coalfield in 2015 are higher, indicating that the vegetation in the central and southern areas of the coalfield was growing, and the ecological environment of the coalfield had recovered.

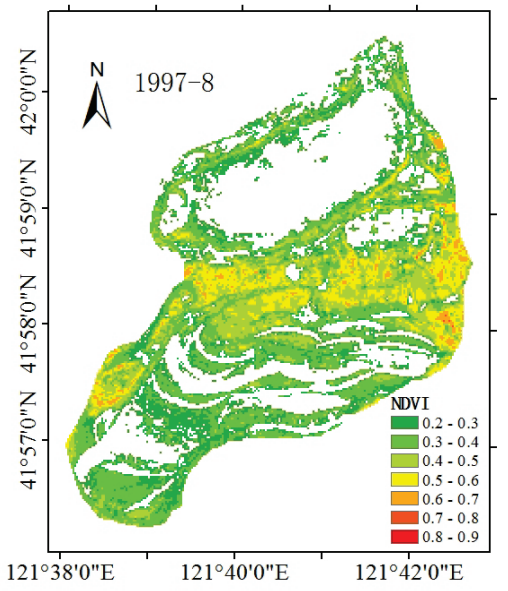

(a) 1997

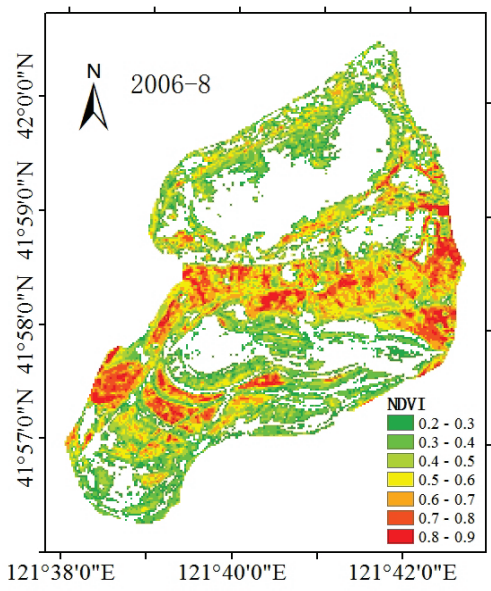

(b) 2006

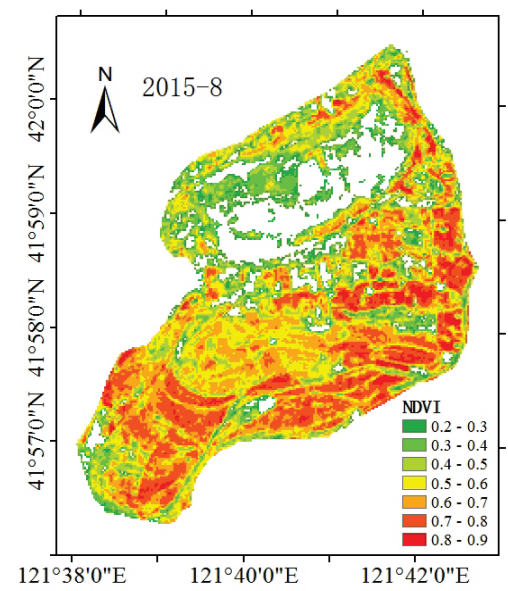

(c) 2015

Figure 6 Spatial distribution of NDVI of Haizhou open-pit coalfield

Table 2 Monthly mean NDVI values of vegetation cover area in Gulianhe coalfield

\begin{tabular}{|c|c|c|c|c|c|c|c|c|c|c|c|c|}
\hline Year & Jan & Feb & Mar & Apr & May & Jun & Jul & Aug & Sep & Oct & Nov & Dec \\
\hline 1999 & 1 & 0,033 & 1 & 0,307 & 0,434 & 0,577 & 0,769 & 0,652 & 0,435 & 0,073 & 0,072 & 1 \\
\hline 2000 & 0,036 & 0,030 & 0,022 & 1 & 0,323 & 0,451 & 0,762 & 0,758 & 0,540 & I & 0,060 & 0,073 \\
\hline 2001 & 1 & 1 & 0,033 & 0,214 & 0,294 & 0,676 & 0,821 & 0,760 & 0,421 & 0,280 & 0,260 & 0,212 \\
\hline 2002 & 0,062 & 0,048 & 0,096 & 1 & 0,306 & 0,606 & 0,605 & 0,795 & 0,610 & 0,391 & 0,423 & 0,195 \\
\hline 2003 & 0,150 & 1 & 0,199 & 0,253 & 1 & 0,350 & 0,570 & 0,745 & 0,580 & 0,265 & 0,087 & 0,064 \\
\hline 2004 & 0,037 & 0,043 & I & 1 & 0,265 & 0,650 & 1 & 0,755 & 1 & 0,343 & 0,177 & 0,127 \\
\hline 2005 & 0,100 & 1 & 0,087 & 0,137 & 0,347 & 0,586 & 0,724 & 0,691 & 0,510 & 0,251 & 0,084 & 1 \\
\hline 2006 & 1 & 0,035 & 1 & 0,180 & 1 & 0,390 & 0,724 & 0,760 & 0,708 & 0,348 & 1 & 1 \\
\hline 2007 & 1 & 0,056 & 0,082 & 0,158 & 1 & 0,616 & 0,586 & 0,688 & 0,210 & 0,343 & 1 & 1 \\
\hline 2008 & 0,165 & 0,112 & 0,168 & 1 & 0,117 & 0,647 & 0,622 & 0,740 & 0,501 & 0,347 & 0,089 & 1 \\
\hline 2009 & I & 0,080 & 0,052 & 1 & 0,375 & 0,644 & 0,716 & 0,670 & I & 0,388 & 0,125 & 1 \\
\hline 2010 & 1 & 0,064 & 0,077 & 0,176 & 0,275 & 0,538 & 0,506 & 0,683 & 0,512 & 0,038 & 1 & 1 \\
\hline 2011 & 1 & 0,060 & 0,069 & 0,237 & 0,274 & 0,639 & 0,671 & 0,679 & 0,391 & 0,164 & 1 & 1 \\
\hline 2012 & 1 & 1 & 0,235 & 0,230 & 0,263 & 0,493 & I & 0,763 & 0,428 & I & 0,153 & 1 \\
\hline 2013 & 1 & 0,065 & 0,097 & I & 0,247 & 0,650 & 1 & 0,676 & 0,406 & 0,186 & 0,130 & 0,194 \\
\hline 2014 & 1 & 1 & 0,164 & 0,243 & 0,333 & 0,606 & 0,657 & 0,667 & 0,441 & 1 & 0,034 & 0,129 \\
\hline 2015 & 0,064 & 1 & 0,056 & 0,177 & 0,304 & 0,450 & 0,635 & 0,697 & 0,425 & 0,368 & 0,082 & 0,079 \\
\hline
\end{tabular}

\subsection{Variation Tendency of NDVI in Gulianhe Coalfield}

Tab. 2 lists the monthly mean NDVI values of the vegetation cover area in Gulianhe coalfield. The annual maximum NDVI values of the Gulianhe coalfield vary between 0,667 and 0,821 . To mitigate the effect of meteorological factors on the annual maximum NDVI values, we outlined the scatter plot of maximum NDVI values from 1999 to 2015, and we depicted the fitting line of NDVI maximum values of Gulianhe coalfield varying 
with time (Fig. 7), with the slope of the fitting line of 0,00677. Fig. 7 illustrates that the NDVI maximum value of Gulianhe open pit decreases. The scatter plot of vegetation cover area in the coalfield is shown in Fig. 8, and the fitting line of vegetation cover area of coalfield is illustrated, with the slope of the fitting line of $-0,77405$. Fig. 8 shows that the vegetation cover area in the coalfield decreases linearly.

The variation tendency of the quarterly averages of NDVI of Gulianhe coalfield is shown in Fig. 9. The NDVI average of the Gulianhe coalfield in the first quarter varies between 0,15 and $-0,21$; the NDVI value in

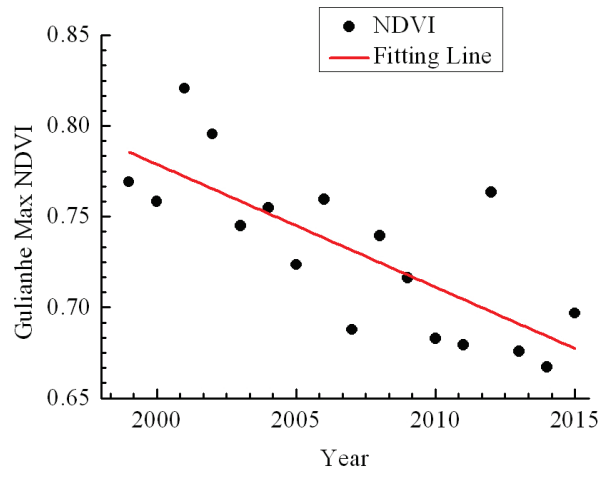

Figure 7 Trend of annual maximum NDVI in Gulianhe coalfield

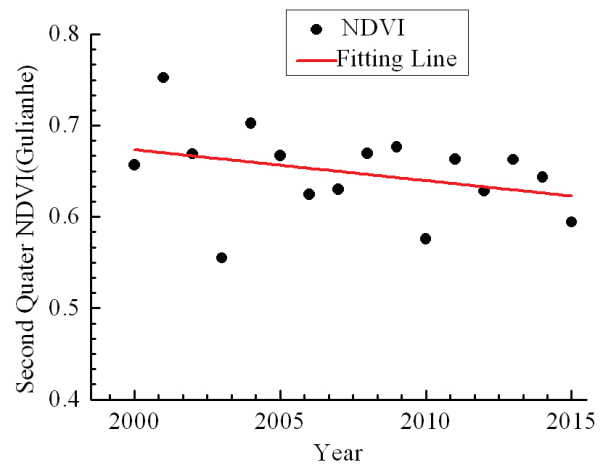

(a) Second quarter

Figure 9 Average seasonal NDVI trends in Gulianhe coalfield

To further demonstrate the spatial distribution and change of vegetation growth, we plotted the spatial distribution of NDVI of Gulianhe coalfield using the August data in 1999, 2005, 2010, and 2014 (Fig. 10). In Fig. 10a, the Gulianhe exploitation area is located in the middle of the coalfield and near the eastern part of the coalfield. With the continuous expansion of the exploitation area, the pit and the dump areas are also continuously expanding. The vegetation cover area and the NDVI in the coalfield decrease rapidly. Considering that Gulianhe is in permafrost zones, the damaged vegetation area is difficult to restore. In the spatial distribution diagram (Fig. 10d) of NDVI of the Gulianhe coalfield in August 2014, the vegetation cover area is mainly distributed in the north and the northeast sides of the coalfield, and the NDVI value of the adjacent area decreases obviously. the second quarter varies between 0,55 and 0,80 , with the slope of fitting line of $-0,00338$; the NDVI value in the third quarter varies between 0,20 and 0,40 , with the slope of fitting line of $-0,00291$; the NDVI value in the fourth quarter varies between 0,06 and 0,14 , with the NDVI value basically remained unchanged. The fitting lines of NDVI in the second and the third quarters assumed a downward trend, indicating that from 1999 to 2015, with the exploitation of coal resources, the vegetation health decreased. The vegetation health was significantly affected by mining activities.

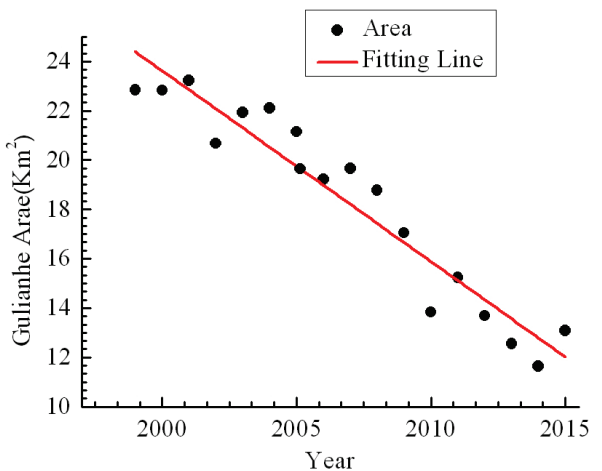

Figure 8 Trend of vegetation coverage in Gulianhe coalfield

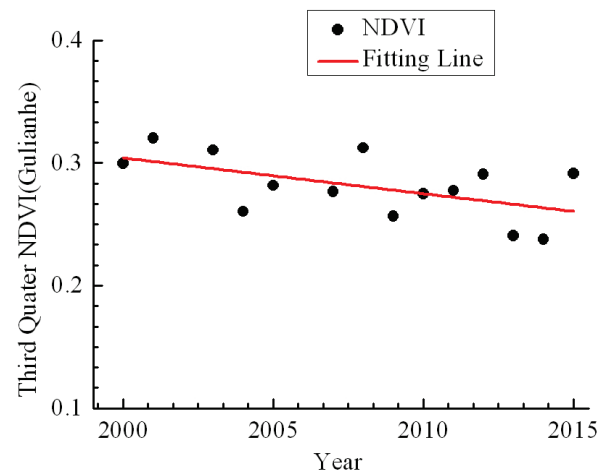

(b) Third quarter

\subsection{Variation Tendency of NDVI in Huolinhe Coalfield}

Tab. 3 presents the monthly mean NDVI values of the vegetation coverage area in Huolinhe coalfield. The annual maximum NDVI values of the Huolinhe coalfield vary between 0,397 and 0,562 . For an enhanced analysis of the variation of annual maximum NDVI values of the coalfield, we drew the scatter plot of the maximum NDVI from $2000 \div 2015$ by adjusting the fitting line of the annual maximum value of NDVI, with a slope of 0,00488 (Fig. 11). Fig. 11 shows that the monthly mean NDVI values of the Huolinhe coalfield exhibit a stable trend with slight increase. The diagram of variation tendency of the vegetation cover area in Huolinhe coalfield is shown in Fig. 12, and the slope of the fitted line is $-0,65984$. The vegetation cover area in the coalfield decreases linearly.

The diagram of the variation tendency of quarter averages of NDVI of Huolinhe coalfield is shown in Fig. 13. The monthly NDVI average of the Huolinhe coalfield in the first quarter varies between 0,08 and $-0,19$, with the slope of fitting line of 0,0042 ; the NDVI value in the 
second quarter varies between 0,31 and 0,45 , with the slope of fitting line of 0,00629 ; the NDVI value in the third quarter varies between 0,21 and 0,33 , with the slope of fitting line of 0,00774 ; the NDVI value in the fourth

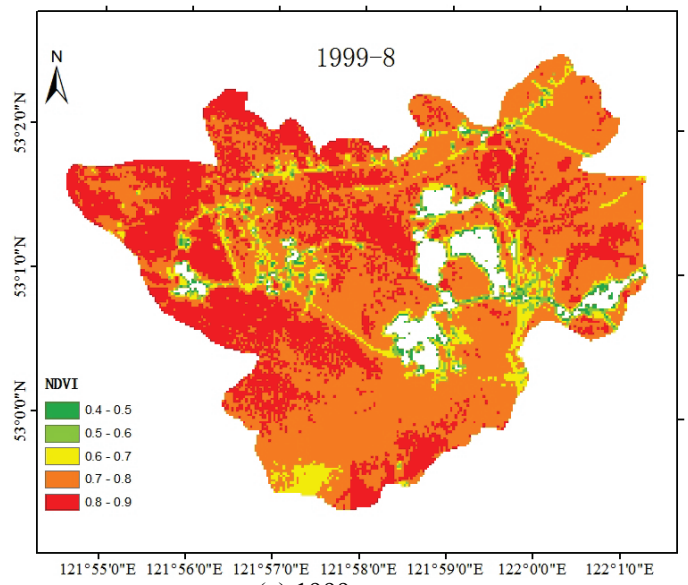

(a) 1999

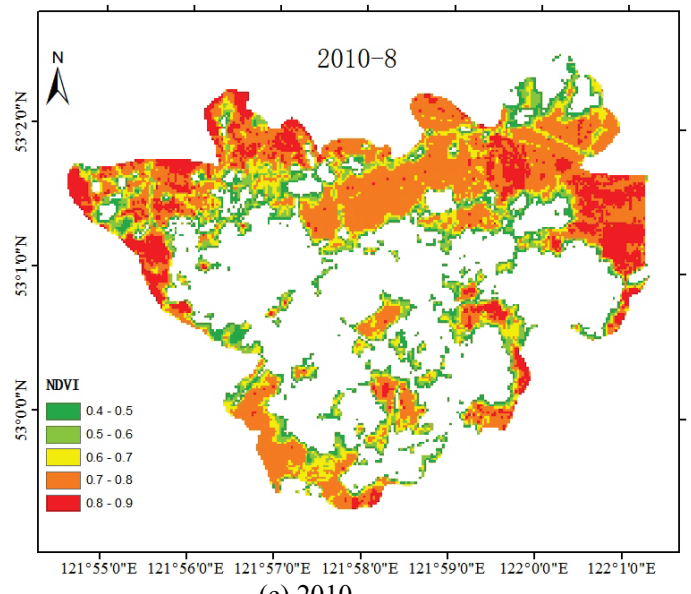

(c) 2010 quarter varies between 0,02 and 0,09 , with the slope of fitting line of 0,00353 . In Fig. 13, the NDVI of the four quarters exhibit a slight upward trend, and the amplitude and trend of the second and third quarters are obvious.

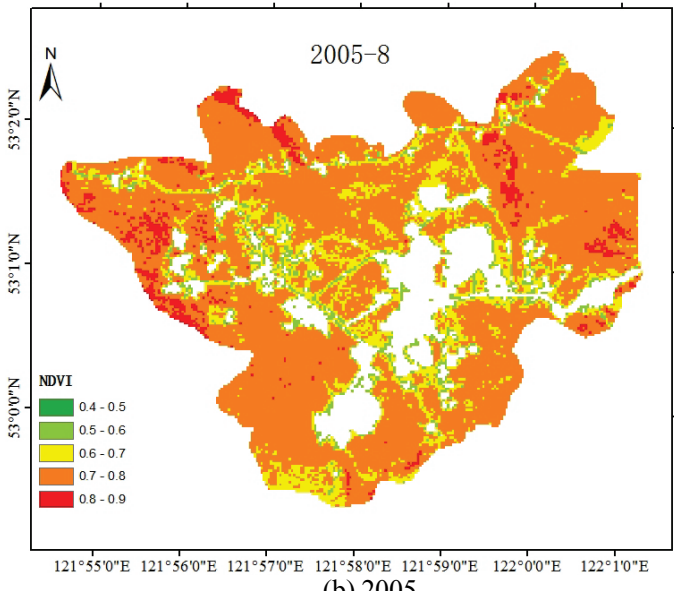

(b) 2005

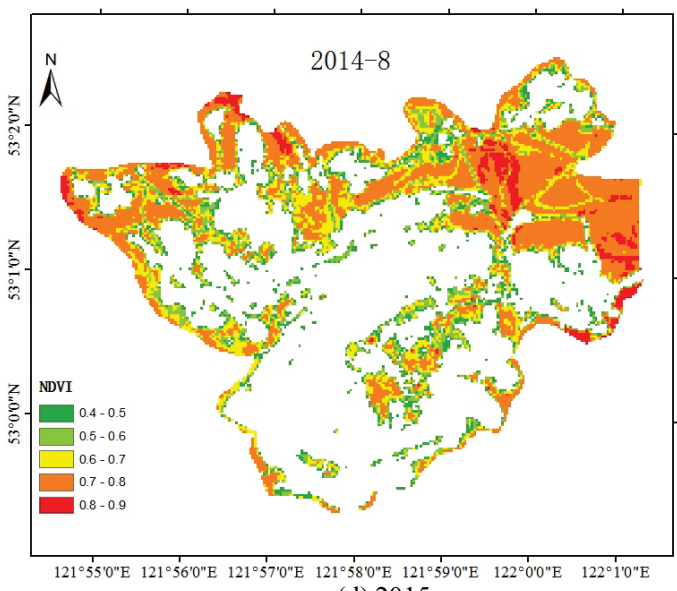

(d) 2015

Figure 10 Spatial distribution of NDVI of Gulianhe open-pit coalfield

Table 3 Monthly mean NDVI values of vegetation cover area in Huolinhe coalfield

\begin{tabular}{|c|c|c|c|c|c|c|c|c|c|c|c|c|}
\hline Year & Jan & Feb & Mar & Apr & May & Jun & Jul & Aug & Sep & Oct & Nov & Dec \\
\hline 2000 & $/$ & $/$ & $/$ & 0,094 & 0,136 & $/$ & $/$ & 0,503 & $/$ & 0,148 & 0,030 & 0,020 \\
\hline 2001 & $/$ & $/$ & 0,010 & 0,051 & 0,128 & 0,188 & 0,222 & 0,485 & 0,189 & 0,132 & 0,131 & 0,106 \\
\hline 2002 & 0,150 & 0,026 & 0,111 & 0,184 & 0,153 & 0,178 & 0,311 & $/$ & 0,398 & 0,050 & $/$ & $/$ \\
\hline 2003 & $/$ & 0,094 & 0,087 & 0,178 & 0,285 & 0,271 & $/$ & 0,485 & 0,089 & 0,244 & 0,228 & 0,011 \\
\hline 2004 & 0,014 & $/$ & 0,050 & 0,146 & 0,201 & 0,225 & 0,449 & $/$ & 0,422 & 0,240 & 0,223 & 0,040 \\
\hline 2005 & 0,008 & 0,010 & $/$ & 0,078 & 0,136 & 0,240 & 0,477 & 0,545 & 0,482 & 0,232 & 0,124 & 0,035 \\
\hline 2006 & 0,012 & 0,009 & 0,021 & 0,091 & 0,132 & 0,224 & 0,355 & 0,547 & 0,368 & 0,087 & 0,124 & $/$ \\
\hline 2007 & 0,008 & 0,006 & 0,070 & 0,107 & 0,104 & 0,264 & $/$ & 0,397 & 0,335 & 0,265 & 0,149 & 0,048 \\
\hline 2008 & $/$ & 0,043 & 0,047 & 0,188 & 0,208 & 0,016 & $/$ & 0,559 & 0,420 & 0,202 & 0,062 & 0,032 \\
\hline 2009 & 0,037 & 0,055 & 0,068 & 0,080 & 0,158 & 0,098 & 0,406 & 0,431 & 0,147 & 0,224 & 0,179 & 0,048 \\
\hline 2010 & 0,022 & 0,052 & 0,031 & 0,110 & 0,250 & 0,323 & 0,349 & 0,433 & $/$ & 0,294 & 0,221 & 0,055 \\
\hline 2011 & 0,008 & 0,025 & $/$ & 0,143 & 0,211 & 0,331 & 0,388 & 0,554 & 0,151 & 0,240 & 0,078 & 0,074 \\
\hline 2012 & 0,029 & 0,074 & $/$ & 0,160 & 0,195 & 0,329 & 0,439 & 0,562 & 0,521 & 0,259 & 0,113 & $/$ \\
\hline 2013 & $/$ & $/$ & 0,105 & 0,161 & 0,128 & $/$ & 0,545 & 0,558 & $/$ & 0,292 & 0,270 & 0,193 \\
\hline 2014 & 0,013 & 0,042 & 0,190 & 0,180 & 0,313 & $/$ & 0,470 & 0,558 & 0,440 & 0,266 & 0,268 & 0,085 \\
\hline 2015 & 0,045 & 0,053 & 0,073 & 0,138 & 0,219 & 0,275 & 0,410 & 0,558 & 0,454 & 0,308 & 0,006 & 0,012 \\
\hline
\end{tabular}

We plotted the spatial distribution of NDVI using the August data in 2001, 2006, 2008, and 2015 (Fig. 14). The exploitation area of Huolinhe coalfield is mainly located in the eastern part of the coalfield, and the direction of the pit is from southwest to the northeast; the dump areas of coalfield are mainly located in the northern (toward the east) and the southern part of the coalfield. Therefore, in the spatial distribution diagram of NDVI, large areas of the non-vegetation cover area appear in the eastern part of the coalfield as shown in Figs. 14a and 14b. With the continuous expansion of the central exploitation area, the vegetation cover area in the coalfield is reduced (Figs. 14c and $14 \mathrm{~d})$. As the exploitation area moves southward, the dump areas on the north side of the coalfield are 
reclaimed. In Fig. 14d, the vegetation cover area has obviously increased. Water bodies exist in the northwest corner of the coalfield. Given that the soil moisture contents of this area are relatively high, the vegetation health is relatively good, and the corresponding NDVI values are high. The western terrain of coalfield is hilly

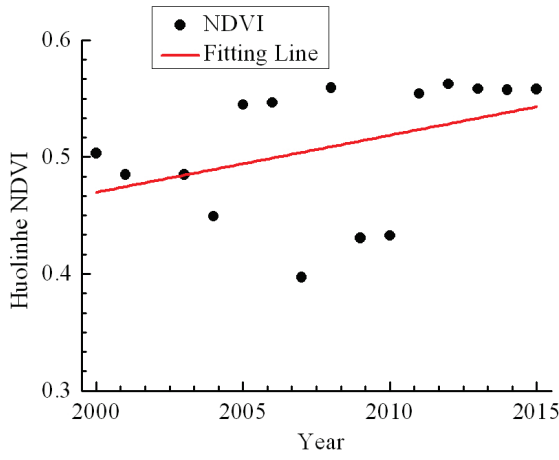

Figure 11 Trend of annual maximum NDVI in Huolinhe coalfield

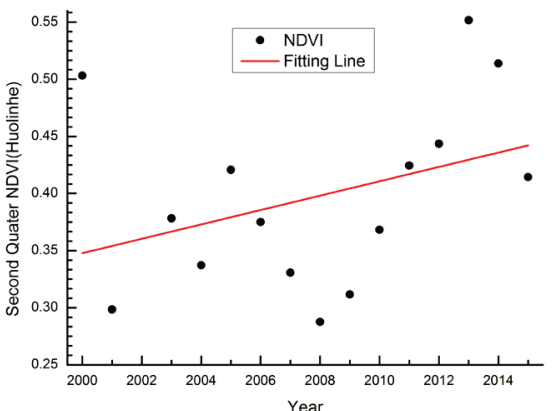

(a) Second quarter

Figure 13 Average quarterly NDVI trends in Huolinhe land with thin earth; this area is dominated by shrubs, and NDVI is low. The east dump areas at the north side of the coalfield (toward east) also feature lush vegetation after restoration; thus, the NDVI value in this area is high based on the spatial distribution diagram in August 2015.

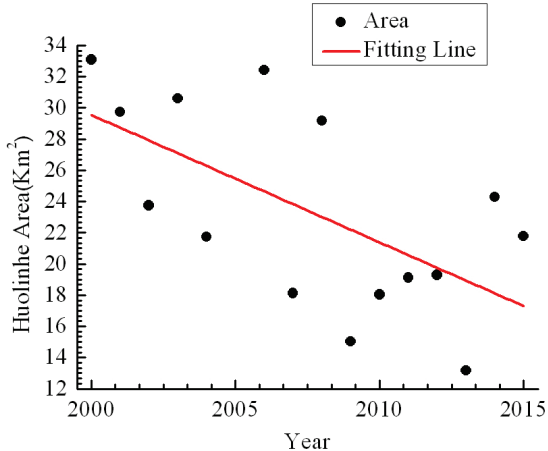

Figure 12 Trend of vegetation coverage in Huolinhe coalfield

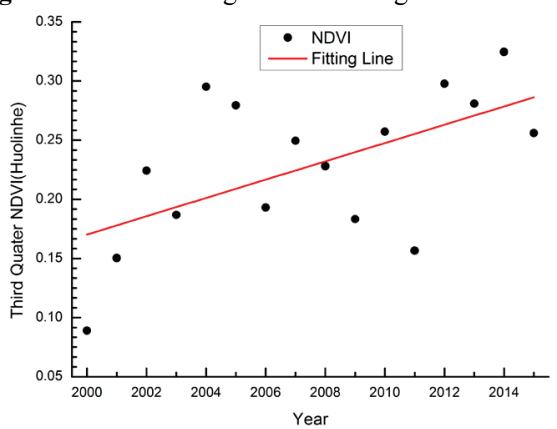

(b) Third quarter

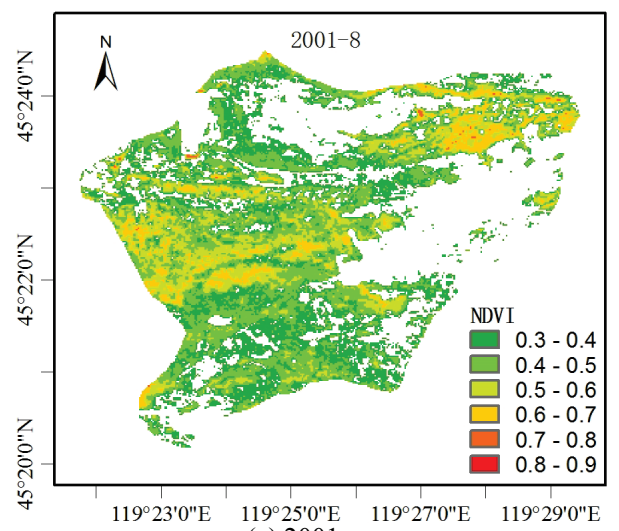

(a) 2001

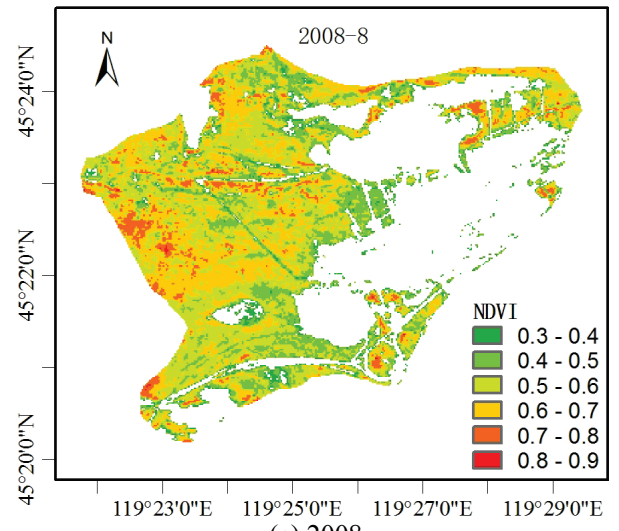

(c) 2008

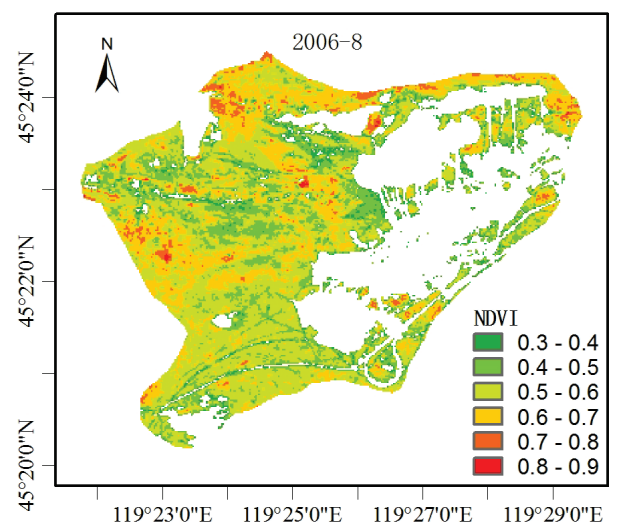

(b) 2006

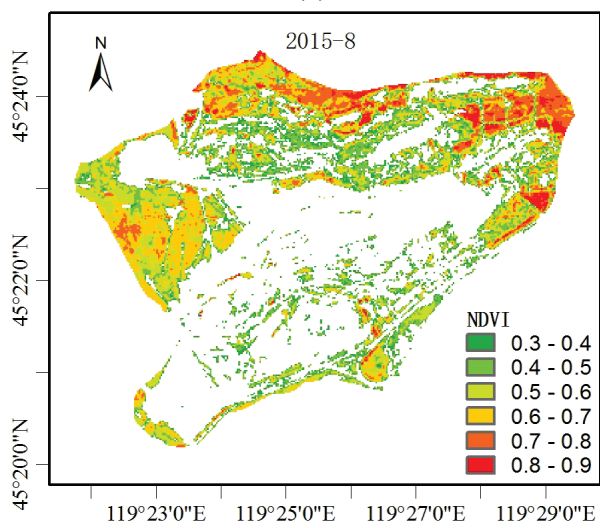

(d) 2015

Figure 14 Spatial distribution of NDVI of Huolinheopen-Pit coalfield 


\subsection{Analysis on correlation between NDVI variations and meteorological factors}

In addition to coal mining activities, meteorological factors affect NDVI variations. Meteorological conditions also determine the difficulty of reclamation in the exploitation area. Therefore, we also analyzed the correlations between NDVI variations and air temperature and precipitation.

To analyze the correlation between monthly NDVI and air temperature, we drew the scatter plot using monthly mean NDVI and air temperature (Fig. 15). The correlation between NDVI and air temperature in every coalfield is extremely strong. Gulianhe has the highest latitude and the lowest temperature, and its vegetation growth has the greatest susceptibility to the temperature. Haizhou has the lowest latitude and the relatively high mean temperature, and its vegetation growth has the lowest susceptibility to the temperature. The temperature exerts a moderate effect on Huolinhe coalfield.
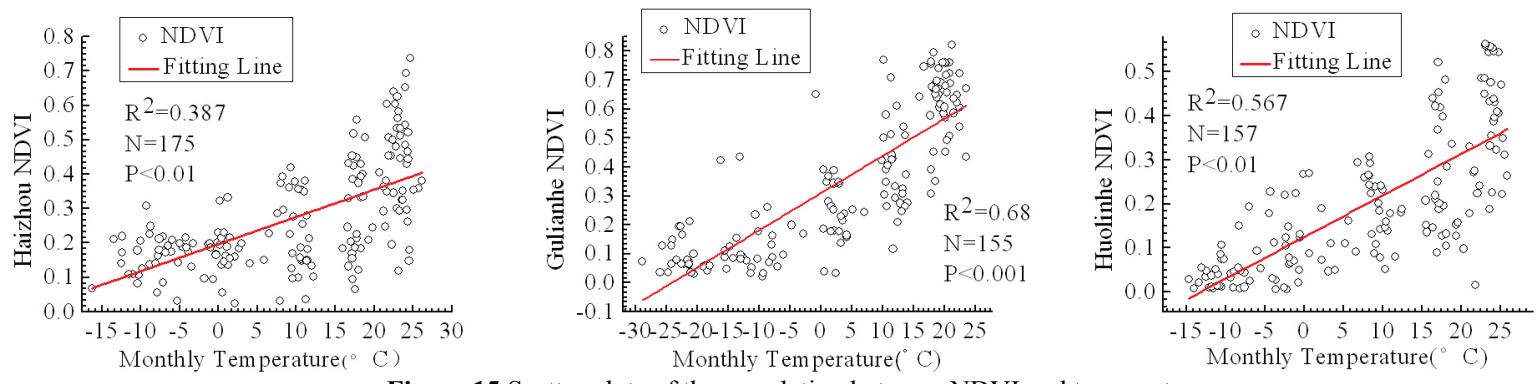

Figure 15 Scatter plots of the correlation between NDVI and temperature

Precipitation is also one of the climatic factors affecting vegetation growth. To analyze the correlation between precipitation and NDVI, we use the monthly mean NDVI and precipitation to mark the scatter plots; the results are shown in Fig. 16. A significant correlation is observed between monthly mean NDVI and precipitation. In Gulianhe coalfield, NDVI exhibits the greatest correlation with precipitation, with the determination coefficient of 0,467. The NDVIs of Haizhou and Huolinhe coalfields show a relatively weaker correlation with precipitation, with the determination coefficients of 0,271 and 0,275 , respectively. Compared with temperature, the NDVI of each coalfield is less affected by precipitation.
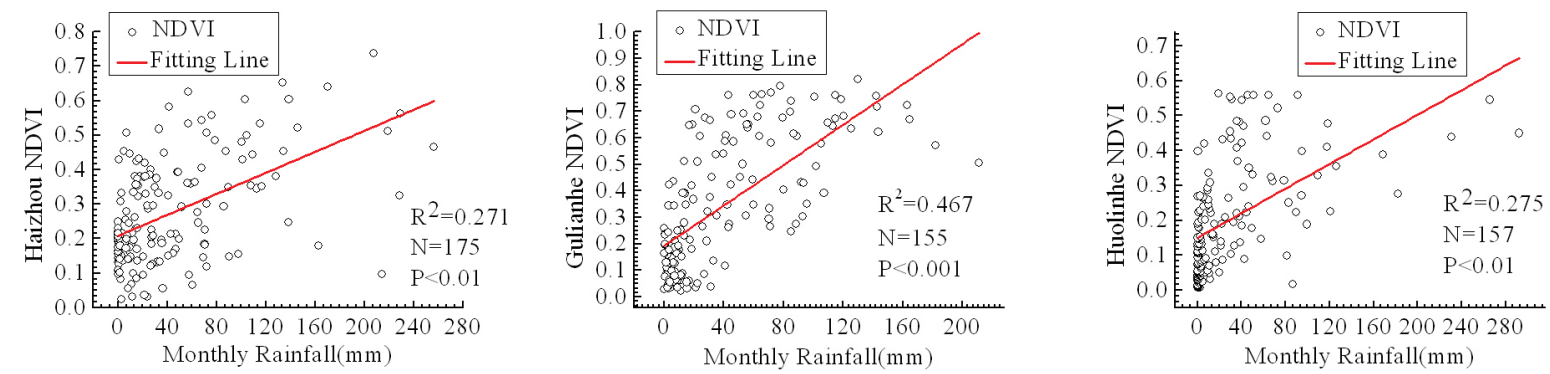

Figure 16 Scatter plots of the correlation between NDVI and precipitation

\subsection{Discussion}

The NDVIs of Haizhou, Gulianhe, and Huolinhe coalfields show different variation tendencies. The NDVI of Haizhou coalfield displays increasing tendency, whereas that of Gulianhe coalfield displays declining tendency; NDVI of Huolinhe coalfield shows a tendency of stability with a slight increase. Haizhou coalfield is rebuilt and converted into a national mine park after closing in 2005, and its dump areas are restored and reclaimed. These factors assist in improving the ecological environment of Haizhou coalfield. In addition, compared with other coalfields, Haizhou is located in the southernmost areas; thus, the reclamation of coalfield can be achieved easily. The exploitation activities in Gulianhe coalfield have damaged large areas of surface vegetation coverage, lowering the surface water content. By contrast, the Gulianhe coalfield belongs to permafrost zones, and restoring and improving the bare soil in the coalfield is difficult, and the dump areas that are abandoned after exploitation cannot be restored instantly. These factors cause an obvious reduction in the vegetation cover area and the mean NDVI value. With the expansion of mining area, the vegetation cover area of Huolinhe coalfield displays a decreasing trend. Huolinhe coalfield is characterized by high degree of modernization, and concerns are being attached to the timely restoration of coalfield environment, and thus the abandoned dump areas had been afforested and reclaimed. The vegetation health of Huolinhe coalfield is basically stable.

\section{Conclusion}

To analyze the influence of coal exploitation on the ecological environment of coalfields in cold and arid regions, we used Landsat time series images to extract the monthly NDVIs of Haizhou, Gulianhe, and Huolinhe coalfields and analyzed the changes and tendencies of the ecological environment of the three coalfields based on 
the NDVI variations. The main conclusions are as follows:

(1) The coalfields in permafrost zones (e.g. Gulianhe coalfield) exhibit a declining tendency in the annual maximum NDVI, quarterly average NDVI, and vegetation cover area. This result indicates that the coalfields in permafrost zones in the past 15 years have been suffering from ecological environment deterioration.

(2) Although the annual maximum and quarterly average NDVI of the coalfields under exploitation in nonpermafrost zones (e.g. Huolinhe coalfield) have been rather stable in the past 15 years, the vegetation area in the coalfields has been declining linearly. This result shows that coal exploitation leads to ecological environment deterioration.

(3) The NDVI and vegetation cover area have improved after the coalfield (e.g. Haizhou coalfield) has been closed, indicating that the ecological environment of coalfield has greatly enhanced because of the reclamation of the coalfield.

(4) Compared with precipitation, temperature exerts a greater effect on the ecological status of the vegetation in cold coalfields; the higher the latitude, the lower the temperature, and the greater the destructive effect of exploitation activities on the ecological environment of the coalfields. Therefore, from an ecological point of view, reducing the construction of open-pit coalfield in cold zones and lessening the output of coalfields are crucial.

We analyzed and evaluated the extent to which coal exploitation damages the ecological environment in Northeast China. This analysis provided the decisionmaking basis for the construction of large-scale open-pit coalfield in the north side of China in the future. However, we only selected image data of the past 15 years and analyzed the changes of ecological environment in coalfields. Considering that we did not compare or analyze the conditions of local vegetation growth before and after coal exploitation, we cannot accurately explain the influence on the ecological conditions of vegetation in the coalfields before and after coal exploitation activities. In future research, increasing the time span of the study and analyzing the changes of the vegetation before and after exploitation in different stages are necessary to objectively and accurately examine and evaluate the effects of the exploitation activities on the ecological environment of the coalfields.

\section{Acknowledgement}

The authors would like to acknowledge the National Natural Science Foundation of China (No. 41671383).

\section{References}

[1] Erener, A. Remote Sensing of Vegetation Health For Reclaimed Areas of Seyitömer Open Cast Coal Mine. // International Journal of Coal Geology. 86, 1(2011), pp. 2026. DOI: 10.1016/j.coal.2010.12.009

[2] Sarp, G. Determination of Vegetation Change Using Thematic Mapper Imagery in Afsin-Elbistan Lignite Basin; SE Turkey. // $1^{\text {st }}$ World Conference on Innovation and Computer Sciences (2011). / Bahcesehir University, Istanbul Turkey. Procedia Technology (Editor: Karahoca A;
Kanbul, S), 1(2012), pp. 407-411.

[3] Lei, S. G.; Ren, L. X.; Bian, Z. F. Time-space Characterization of Vegetation in A Semiarid Mining Area Using Empirical Orthogonal Function Decomposition of MODIS NDVI Time Series. // Environment Earth Science. 75, 516(2016), pp. 1-11. DOI: 10.1007/s12665-015-5122-z

[4] Chen, J.; Li, K.; Chang, K.; Sofia, G.; Tarolli, P. Open-pit Mining Geomorphic Feature Characterisation. // International Journal of Applied Earth Observation and Geoinformation. 42(2015), pp. 76-86. DOI: 10.1016/j.jag.2015.05.001

[5] Li, Y. F.; Liu, Y. H.; Du, Z. P.; Chen, J. Effect of Coal Resources Development and Compensation for Damage to Cultivated Land in Mining Areas. // Mining Science and Technology (China). 19, 5(2009), pp. 620-625. DOI: 10.1016/S1674-5264(09)60115-0

[6] Bian Z. F.; Lei S. G.; Inyang H. I.; Chang L. Q.; Zhang, R.; Zhou C. J.; He X. Integrated Method of RS and GPR for Monitoring the Changes of Soil Moisture and Ground Water Environment Due to Underground Coal Mining. // Environmental Geology. 57, 1( 2009), pp. 131-142. DOl: 10.1007/s00254-008-1289-x

[7] Zhang, J. P.; Zhang, L. B.; Xu, C.; Liu, W. L.; Qi, Y.; Wo, $\mathrm{X}$. Vegetation Variation of Mid-Subtropical Forest Based on MODIS NDVI Data-A Case Study of Jinggangshan City, Jiangxi Province. // Acta Ecologica Sinica. 34, 1(2014), pp. 7-12. DOI: 10.1016/j.chnaes.2013.09.005

[8] Eckert, S.; Hüsler, F.; Liniger, H.; Hodel, E. Trend Analysis of MODIS NDVI Time Series for Detecting Land Degradation and Regeneration in Mongolia. // Journal of Arid Environments. 113(2015), pp. 16-28. DOI: 10.1016/j.jaridenv.2014.09.001

[9] Vasileiou, E.; Stathopoulos, N.; Stefouli, M.; Charou, E.; Perrakis, A. Evaluating the Environmental Impacts after The Closure of Mining Activities Using Remote Sensing Methods - the Case Study of Aliveri Mine Area. // Annual Conference 2012 of International Mine Water Association. / Bunbury, Australia, 2012, pp. 755-763.

[10] Kapackova, V. Using Multiple Spectral Feature Analysis for Quantitative PH Mapping in A Mining Environment. // International Journal of Applied Earth Observation and Geoinformation. 28(2014), pp. 28-42. DOI: 10.1016/j.jag.2013.10.008

[11] Kumar, A.; Pandey, A. C. Evaluating Impact of Coal Mining Activity on Landuse/Landcover Using Temporal Satellite Images in South Karanpura Coalfields and Environs, Jharkhand State, India. // International Journal of Advanced Remote Sensing and GIS. 2, 1(2013), pp. 183197.

[12] Charou, E.; Stefouli, M.; Dimitrakopoulos, D.; Vasiliou, E.; Mavrantza, O. D. Using Remote Sensing to Assess Impact of Mining Activities on Land And Water Resources. // Mine Water and The Environment. 29, 1(2010), pp. 45-52. DOI: 10.1007/s10230-010-0098-0

[13] Maxwell, A. E.; Warner, T. A.; Strager, M. P.; Conley, J. F.; Sharp, A. L. Assessing Machine-Learning Algorithms and Image- and Lidar-Derived Variables for GEOBIA Classification of Mining and Mine Reclamation. // International Journal of Remote Sensing. 36, 4(2015), pp. 954-978. DOI: 10.1080/01431161.2014.1001086

[14] Petropoulos, G. P.; Partsinevelos, P.; Mitrak, Z. Change Detection of Surface Mining Activity and Reclamation Based on A Machine Learning Approach of MultiTemporal Landsat TM Imagery. // Geocarto International. 28, 4(2013), pp. 323-342. DOI: 10.1080/10106049.2012.706648

[15] Yang, J. J. Detecting Landscape Changes Pre-and Post Surface Coal Mining in Indiana, USA. // Geographic Information Sciences. 14, 1(2008), pp. 36-43. DOI: 10.1080/10824000809480637 
[16] Sonwalkar, M.; Fang, L.; Sun, D. L. Use of NDVI Dataset for A GIS Based Analysis: A Sample Study of TAR Creek Superfund Site. // Ecological Informatics. 5, 6(2010), pp. 484-491. DOI: 10.1016/j.ecoinf.2010.07.003

[17] Townsend, P. A.; Helmers, D. P.; Kingdon, C. C.; McNeil, B. E.; Beurs, K. M.; Eshleman, K. N. Changes in The Extent of Surface Mining and Reclamation in The Central Appalachians Detected Using A 1976-2006 Landsat Time Series. // Remote Sensing of Environment. 113, 1(2009), pp. 62-72. DOI: 10.1016/j.rse.2008.08.012

[18] Zhang, B.; Wu, D.; Zhang, L.; Jiao, Q. J.; Li, Q. T. Application of Hyperspectral Remote Sensing for Environment Monitoring in Mining Areas. // Environmental Earth Science. 65, 3( 2012), pp. 649-658. DOI: 10.1007/s12665-011-1112-y

[19] Zawadzki, J.; Przezdziecki, K.; Miatkowski, Z. Determining The Area of Influence of Depression Cone in The Vicinity of Lignite Mine by Means of Triangle Method and Landsat TM/ETM+ Satellite Images. // Journal of Environmental Management. 166(2016), pp. 605-614. DOI: 10.1016/j.jenvman.2015.11.010

[20] Tian, F.; Wang, Y. J.; Fensholt, R.; Wang, K.; Zhang, L,; Huang, Y. Mapping and Evaluation of NDVI Trends from Synthetic Time Series Obtained by Blending LANDSAT and MODIS Data Around A Coalfield on The Loess Plateau. // Remote Sensing. 5, 9(2013), pp. 4255-4279. DOl: 10.3390/rs5094255

[21] Lei, S. G.; Bian, Z. F.; Daniels, J. L.; He, X. SpatioTemporal Variation of Vegetation in An Arid And Vulnerable Coal Mining Region. // Mining Science and Technology (China). 20, 3(2010), pp. 485-490. DOl: 10.1016/S1674-5264(09)60230-1

[22] Liu, X. Y.; Zhou, W.; Bai, Z. K. Vegetation Coverage Change and Stability in Large Open-Pit Coal Mine Dumps in China During 1990-2015. // Ecological Engineering. 95(2016), pp. 447-451. DOI: 10.1016/j.ecoleng.2016.06.051

\section{Authors' addresses}

Wenbin Sun, PhD, Associate Professor (Corresponding author) College of Geo-science and Surveying Engineering, University of Mining \& Technology (Beijing), D11, Xueyuan Road, Haidian District, Beijing, 100083 P. R. China E-mail: swb@cumtb.edu.cn

\section{Hongdan Zhang, M.Sc.}

College of Geo-science and Surveying Engineering, University of Mining \& Technology (Beijing),

D11, Xueyuan Road, Haidian District, Beijing, 100083 P. R. China E-mail: 464257242@qq.com

\section{Yungang Cao, PhD, Associate Professor}

Faculty of Geosciences and Environmental Engineering, Southwest Jiaotong University,

The Western Park of the Hi-Tech Industrial Development Zone, Chengdu, Sichuan Province, 611756, P. R. China

E-mail: yungang@swjtu.edu

\section{Xiaolei Zhang, M.Sc.}

College of Geo-science and Surveying Engineering, University of Mining \& Technology (Beijing),

D11, Xueyuan Road, Haidian District, Beijing, 100083 P. R. China E-mail: 278055472@qq.com

\section{Xuefeng Ji, M.Sc.}

College of Geo-science and Surveying Engineering, University of Mining \& Technology (Beijing),

D11, Xueyuan Road, Haidian District, Beijing, 100083 P. R. China E-mail:1027046389@qq.com

Fashuai Li, M.Sc.

Faculty of Geo-Information Science and Earth Observation, University of Twente,

Hengelosestraat 99, 7514 AE, Enschede, The Netherlands E-mail: lifashuai@gmail.com 